\title{
Winter Foot and Equipment Traffic Impacts on a 'L93' Creeping Bentgrass Putting Green
}

\author{
Christian M. Baldwin, Haibo Liu ${ }^{1}$, and Lambert B. McCarty \\ Department of Horticulture, Clemson University, $252 P \&$ A Building, \\ Clemson, SC 29634-0319
}

Hong Luo

Department of Genetics and Biochemistry, Clemson University, Clemson, SC 29634-0318

\section{Joe Toler \\ Department of Applied Economics and Statistics, Clemson University, Clemson, SC 29634-0313}

\section{Steven H. Long \\ Palmetto Turf Farms, Effingham, SC 29541}

Additional index words. turfgrass quality, foot traffic, rolling traffic, frost, freezing stress, carbohydrates, chlorophyll, soil bulk density, water infiltration

\begin{abstract}
Creeping bentgrass (Agrostis stolonifera var. palustris Huds.) is desirable as a putting green turfgrass in the transition zone as a result of year-round green color, ball roll, and playability. However, management challenges exist for bentgrass greens, including winter temperature fluctuations. Frosts often cause cancellations or delays of tee time resulting in lost revenue. In response to this winter golf course management issue, a research project was initiated at Clemson University from 1 Dec. 2005 and 2006 to 1 Aug. 2006 and 2007 on a 'L93' creeping bentgrass putting green to determine the impacts of foot traffic or mower traffic and time of traffic application on bentgrass winter performance. Treatments consisted of no traffic (control), foot traffic, and walk-behind mower traffic (rolling) at 0700 and $0900 \mathrm{HR}$ when canopy temperatures were at or below $0{ }^{\circ} \mathrm{C}$. Foot traffic included $\approx 75$ steps within each plot using size $10 \mathrm{SP}-4$ Saddle Nike golf shoes (soft-spiked sole) administered by a researcher weighing $\approx 75 \mathrm{~kg}$. A Toro Greensmaster 800 walk-behind greens mower weighing $92 \mathrm{~kg}$ with a $45.7-\mathrm{cm}$ roller was used for rolling traffic. Data collected included canopy and soil temperatures $(7.6 \mathrm{~cm}$ depth), visual turfgrass quality (TQ), clipping yield $\left(\mathrm{g} \cdot \mathrm{m}^{-2}\right)$, shoot chlorophyll concentration $\left(\mathrm{mg}^{-1} \mathrm{~g}^{-1}\right)$, root total nonstructural carbohydrates (TNC) $\left(\mathrm{mg}^{-1} \mathrm{~g}^{-1}\right)$, soil bulk density $\left(\mathrm{g} \cdot \mathrm{cm}^{-3}\right)$, and water infiltration rates $\left(\mathrm{cm} \cdot \mathrm{h}^{-1}\right)$. Time and type of traffic significantly influenced bentgrass winter performance. On all TQ rating dates, $0700 \mathrm{HR}$ rolling traffic decreased $T Q$ by $\approx \mathbf{1 . 1}$ units compared with foot traffic at $0700 \mathrm{HR}$. In December, regardless of traffic application time, rolling traffic reduced bentgrass shoot growth $\approx 17 \%$. However, in February, chlorophyll, soil bulk density, and water infiltration differences were not detected. By the end of March, all treatments had acceptable TQ. Root TNC was unaffected in May, whereas shoot chlorophyll concentrations were unaffected in May and August. This study indicates bentgrass damage resulting from winter traffic is limited to winter and early spring months and full recovery should be expected by summer.
\end{abstract}

Water vapor condensation settling on turfgrass foliage becomes frost when temperatures approach $0{ }^{\circ} \mathrm{C}$. Winter traffic, whether by foot, equipment, or animal, during periods of frost typically cause damage, leaving turfgrass discolored. Frost accumulation is detrimental because ice crystals damage the protoplasm resulting in possible membrane puncture (Beard, 1973). Also, at colder tem-

Received for publication 13 Dec. 2007. Accepted for publication 12 Feb. 2008.

${ }^{1}$ To whom reprint requests should be addressed; e-mail haiboL@clemson.edu ceeding $30{ }^{\circ} \mathrm{C}$ result in shallow roots $(\mathrm{Xu}$ and Huang, 2000) reduced carbohydrate reserves (Huang and Gao, 2000) and increased disease susceptibility (Huang, 2001). Management techniques to understand and possibly alleviate summer stress have been documented (Bunnell et al., 2004; Guertal et al., 2005; Rodriguez et al., 2005). Furthermore, winter temperature fluctuations within the transition zone present unique challenges in bentgrass management. During winter months in the transition zone, decisions regarding timing of course setup and play are important when temperatures approach $0{ }^{\circ} \mathrm{C}$. Often, tee times are delayed or cancelled resulting in lost revenue and tension between players and superintendents.

Several management techniques are available to minimize winter injury. Using insulated (straw or curled wood mat) protective covers increased soil temperatures by $4.3{ }^{\circ} \mathrm{C}$ and reduced seasonal soil temperature variation, enhancing turfgrass winter survival (Dionne et al., 1999). Lightly syringing greens before daily traffic and restricting golf cart access on fairways, tees, and greens until temperatures exceed $0{ }^{\circ} \mathrm{C}$ can also minimize winter-kill or damage (White, 1984). Application of abscisic acid has been shown to enhance freezing tolerance (Gusta et al., 1996), whereas a proper fertility program can minimize winter injury (Webster and Ebdon, 2005).

Numerous studies have been conducted to determine the diversity of turfgrass freezing stress tolerance (Ebdon et al., 2002; Gusta et al., 1980; Rajashekar et al., 1983) and to determine turfgrass survival with or without snow and ice cover removal (Tompkins et al., 2000, 2004; Valverde and Minner, 2007). All of these studies were performed in northern U.S. climates and to date, research has not been reported attempting to quantify the effects of winter traffic injury on bentgrass grown in the transition zone. Although light to heavy frost occur on most golf courses across the country, daily and seasonal growing conditions vary; therefore, the types of permissible traffic on putting greens need regional investigation. The objectives of this study were to assess variable traffic impacts to a creeping bentgrass putting green during winter months and determine residual effects in spring and summer.

\section{Materials and Methods}

peratures, processes such as photosynthesis and respiration are inhibited as cells enter a gelatinous consistency (Fry and Huang, 2004). However, plants can minimize cellular damage by maintaining an unsaturated fatty acid (double bond between carbon atoms) composition, which enhances membrane fluidity (Cyril et al., 2002), thereby reducing foliage damage.

In the transition zone, creeping bentgrass is desirable as a result of year-round green color, ball roll, and overall playability. However, this turfgrass presents many challenges throughout summer as well as winter seasons. During summer months, temperatures ex-
This research project was conducted at Clemson University, Clemson, SC, from 1 Dec. 2005 and 2006 to 1 Aug. 2006 and 2007 on 'L93' creeping bentgrass field research plots established in 2002 with soil profile construction of U.S. Golf Association recommendations (USGA, 1993). Although simulated traffic treatments were ended on 1 Mar. 2006 and 2007, data collection continued through spring and summer to evaluate any residual effects from winter traffic. Also, routine maintenance traffic as a result of daily mowing continued through spring and summer. Treatments consisted of no 
traffic (control), foot traffic at $0700 \mathrm{HR}$ (F7) and $0900 \mathrm{HR}$ (F9), and walk-behind mower traffic (rolling) at $0700 \mathrm{HR}(\mathrm{R} 7)$ and $0900 \mathrm{HR}$ (R9). Foot traffic included $\approx 75$ steps within each plot using size 10 SP-4 Saddle Nike golf shoes (Nike, Beaverton, OR) (soft-spiked sole), which ensured complete coverage of the plot by a human. The majority of traffic applications for both years was made by an author weighing $75 \mathrm{~kg}$. A Toro Greensmaster 800 walk-behind greens mower (Greensmaster 800; The Toro Company, Bloomington, $\mathrm{MN}$ ) weighing $92 \mathrm{~kg}$ with a $46-\mathrm{cm}$ roller was used to simulate rolling traffic. One pass was made per plot. Plot dimensions were $46 \mathrm{~cm}$ in width by $120 \mathrm{~cm}$ in length; similar width of the mower ensured complete coverage of the plot. Regardless of traffic, the entire plot area was trafficked. Plots were always rolled and not mowed when canopy temperatures were below $0{ }^{\circ} \mathrm{C}$. Mowing occurred over the entire plot area when canopy temperatures were above $7.2{ }^{\circ} \mathrm{C}$ on nontreatment days. Traffic treatments were applied at 0700 and $0900 \mathrm{HR}$ when canopy temperatures (model \#1455; Taylor, Oakbrook, IL) were below $0{ }^{\circ} \mathrm{C}$ at $0700 \mathrm{HR}$.

Depending on air temperature, the bentgrass green was mowed $3.2 \mathrm{~mm}$ three times weekly during winter months. In early January for both years, a combination of $10 \mathrm{~N}-$ $1.3 \mathrm{P}-4.2 \mathrm{~K}$ and $5 \mathrm{~N}-0 \mathrm{P}-5.8 \mathrm{~K}$ liquid fertilizers (Progressive Turf, LLC., Ball Ground, GA) was applied with $\mathrm{N}$ at $4.9 \mathrm{~kg} \cdot \mathrm{ha}^{-1}$. Disease occurrence was nonobservable during the study period; therefore, no fungicides were applied. Beginning in March and continuing through August, mowing occurred six to seven times weekly at $3.2 \mathrm{~mm}$. Nitrogen was provided every 2 weeks at a rate of 9.7 $\mathrm{kg} \cdot \mathrm{ha}^{-1}$ using Progressive Turf liquid fertilizers from 15 Mar. to 31 May 2006 and 2007. After hollow tine aerification (1.3-cm diameter tines $10 \mathrm{~cm}$ in length with $5.0-\mathrm{cm}$ spacing) in Spring 2006 and 2007, N was applied at a rate of $24.4 \mathrm{~kg} \cdot \mathrm{ha}^{-1}$ using $18 \mathrm{~N}-$ $1.3 \mathrm{P}-14.9 \mathrm{~K}$ greens-grade granular fertilizer (Anderson's, Maumee, OH). Chlorothalonil $\left(11.8 \mathrm{~L} \cdot \mathrm{ha}^{-1}\right)$, Azoxystrobin $\left(48.8 \mathrm{~kg} \cdot \mathrm{ha}^{-1}\right)$, and Mefonoxam at $\left(6.4 \mathrm{~L} \cdot \mathrm{ha}^{-1}\right)$ were applied as needed to prevent dollar spot (Sclerotinia homoeocarpa F.T. Bennet), pythium (Pythium spp.), and brown patch (Rhizoctonia solani Kuhn.).

Data collection. Collected data included canopy and soil temperatures (7.6 cm depth) (model \#9840; Taylor), visual turfgrass quality (TQ), clipping yield, chlorophyll concentration, root total nonstructural carbohydrates (TNC), soil bulk density, and water infiltration rates. Canopy and soil $(7.6 \mathrm{~cm}$ depth) temperatures were recorded after each traffic application (24 dates) during winter months at $0700 \mathrm{HR}, 0900 \mathrm{HR}$, and solar noon.

Turfgrass quality ratings were recorded after each treatment application (24 rating dates for both years) based on color, density, texture, and uniformity of the bentgrass surface. Turfgrass quality scores were recorded weekly and averaged per month from Mar. to Aug. 2006 and 2007. Quality was visually evaluated from 1 to 9 with $1=$ brown, dead turfgrass; $6=$ minimal acceptable turfgrass; and $9=$ ideal green, healthy turfgrass.

Clipping yields $\left(\mathrm{g} \cdot \mathrm{m}^{-2}\right)$ were collected after 8, 16, and 24 traffic applications midMay and mid-August for both years. Shoots were harvested with a Toro walk-behind greens mower. For winter collection, the bentgrass green was not mowed for $3 \mathrm{~d}$ to ensure adequate tissue sample resulting from slow shoot growth of bentgrass during the winter. However, for spring and summer collection, the bentgrass green was not mowed for $1 \mathrm{~d}$ before clipping yield collection. After collection, shoots were dried in an $80^{\circ} \mathrm{C}$ oven for $48 \mathrm{~h}$ to ensure complete tissue dehydration and then weighed (McCullough et al., 2006).

Shoot chlorophyll $\left(\mathrm{mg} \cdot \mathrm{g}^{-1}\right)$ was measured after 8, 16, and 24 traffic applications midMay and mid-August for both years. Fresh clippings were collected from each plot using a Toro walk-behind greens mower after $3 \mathrm{~d}$ of growth and immediately placed in a plastic bag inside a covered bucket to prevent sunlight degradation. Clippings were weighed $(0.1 \mathrm{~g})$ and placed in a glass test tube $(1.0 \mathrm{~cm}$ in width and $14.8 \mathrm{~cm}$ in length) with $10 \mathrm{~mL}$ of dimethyl sulfoxide (Hiscox and Israelstam, 1979). Samples were incubated in $65{ }^{\circ} \mathrm{C}$ water on a hot plate (PC-600; Corning, Corning, NY) for $1.5 \mathrm{~h}$ and continuously shaken. Remaining extract ( $2 \mathrm{~mL}$ ) was transferred into cuvettes and absorbance values were recorded at $663-\mathrm{nm}$ and $645-\mathrm{nm}$ wavelengths using a Spectrophotometer (Genesys $^{\mathrm{TM}} 20$; ThermoSpectronic, Rochester, NY). Blanks were initially run and also after every sixth sample as an internal control. The following formula was used to calculate total chlorophyll $\left(\mathrm{mg} \cdot \mathrm{g}^{-1}\right):\left(8.02 * \mathrm{D}_{663}+20.2 *\right.$ $\left.\mathrm{D}_{645}\right) * 0.1$ (Arnon, 1949).

Root tissues for TNC $\left(\mathrm{mg} \cdot \mathrm{g}^{-1}\right)$ analysis was collected first week in May for both years. Root tissue was harvested using a soil bulk density sampler, which extracted 154.4$\mathrm{cm}^{3}$ core samples $(10.2 \mathrm{~cm}$ depth) before sunrise to minimize any diurnal fluctuations. After soil removal, root tissue samples were stored at $-75^{\circ} \mathrm{C}$ until freeze-dried at $-40{ }^{\circ} \mathrm{C}$ for 2 weeks to stop all metabolic activity. Samples were then ground using an A-10 plant grinder (IKA Works, Wilmington, NC). Grounded samples were rehydrated with 100 $\mu \mathrm{L}$ of $80 \%$ ethanol and $2 \mathrm{~mL}$ of $0.1 \mathrm{M}$ sodium acetate buffer ( $\mathrm{pH} 4.5$ ). Rehydrated samples were placed in boiling water for $1 \mathrm{~h}$, cooled for $1 \mathrm{~h}$, and repeated. Then, $2 \mathrm{~mL}$ of invertase (Sigma I-4753, 433 units/mg) and amyloglucosidase (Sigma A-7255, 23,000 units/g) were added to solution. Samples were placed in a water bath $\left(40\right.$ to $45^{\circ} \mathrm{C}$ ) for $3 \mathrm{~d}$ and vortexed three times daily. TNC analysis was analyzed using Nelson's Assay (Nelson, 1944), which determines glucose and fructose in plant tissue (Somogyi, 1945). A $25-\mu \mathrm{L}$ aliquot was removed and two reagents (copper and arsenomolybdate) were added to the solution. Absorbance values were measured at $520 \mathrm{~nm}$ using a spectrophotometer.
Soil bulk density (10.2 cm depth) was collected at the end of February for both years after 24 traffic applications by extracting $154.4-\mathrm{cm}^{3}$ soil cores. Cores were oven dried at $105^{\circ} \mathrm{C}$ for $10 \mathrm{~d}$ to ensure complete water evaporation.

Water infiltration analysis (Bunnell et al., 2001) was performed at the end of February in both years after 24 traffic applications using a double ring infiltrometer (model 13a; Turf-Tec International, Oakland Park, FL). One sample was taken per plot. The outer ring had a diameter of $30.5 \mathrm{~cm}$ and the inner ring $15.2 \mathrm{~cm}$. The infiltrometer was inserted into the turfgrass canopy at a depth of $2.5 \mathrm{~cm}$. Rings were then filled to the top of the infiltrometer with $10.2 \mathrm{~cm}$ of water. After water vacated the center ring, infiltration rates were recorded based on the time it took water to infiltrate into the soil.

Data analysis. Treatments were arranged in a randomized complete block design with six replications. In Year 2, plots were rerandomized within the identical plot dimensions of Year 1 because no residual effects were noted during spring and summer months in Year 1. All statistical computations were conducted using analysis of variance (ANOVA) within the Statistical Analysis System (version 9.1; SAS Institute Inc., 2005). Means were separated by Fisher's least significant difference test with an alpha of 0.05 . Year $\times$ treatment interaction occurred for winter TQ scores; however, differences were scale changes with similar trends. Therefore, pooled data from Year 1 and 2 are presented.

\section{Results}

Coldest monthly canopy temperatures were noted in January. For all months, canopy temperatures at $0700 \mathrm{HR}$ were $\approx 11.2{ }^{\circ} \mathrm{C}$ colder than $0900 \mathrm{HR}$, whereas canopy temperatures at $0900 \mathrm{HR}$ were $\approx 9.8^{\circ} \mathrm{C}$ colder than solar noon. However, no differences were detected for soil temperatures between 0700 and $0900 \mathrm{HR}$, but solar noon soil temperatures were $\approx 3.1{ }^{\circ} \mathrm{C}$ higher than at 0700 and 0900 HR across all months (Table 1).

All traffic treatments TQ was below the acceptable threshold of 6 by third traffic application, whereas control TQ was 7.6 (Table 2). By the sixth traffic application, R7 TQ was 5.3, whereas other treatments remained above 6 . However, F9 (7.1) had a greater TQ score than R9 (6.4), whereas control had the greatest TQ (7.7) score. After nine traffic applications, the R7 treatment had a 5.3 TQ score, whereas F7 had a TQ score of 6.3. Similar trends continued from Day 12 through Day 24 ratings as $\mathrm{R} 7$ reduced TQ by $\approx 1.0$ units compared with F7 TQ. Visual TQ for R9 on two rating dates (Days 18 and 24) showed a 0.9- and 0.5-unit decline compared with F9 TQ. On the last traffic application date, R7 had TQ of 3.7, whereas F7's TQ was 4.8. On all rating dates, $\mathrm{R} 7$ showed $\mathrm{a} \approx 1.4$ unit TQ decrease than R9, whereas F7 reduced TQ by $\approx 1.1$ units compared with F9 on most rating dates. Except R7 (5.8), all 
other treatments reached acceptable TQ by March (Table 3). By April, all treatments were above the acceptable TQ threshold of 6 indicating bentgrass had visually recovered from any winter traffic damage. No TQ differences were noted from May to August ratings; however, TQ scores began to decline for all treatments in August as a result of the onset of summer stress not influenced by this winter study.

Winter traffic significantly impacted clipping yield (Table 4). In December, compared with the control, F7 and F9 reduced clipping yield $\approx 6.5 \%$, whereas $\mathrm{R} 7$ and $\mathrm{R} 9$ reduced clipping yield $\approx 24 \%$, respectively. Similar trends continued in January and February indicating rolling traffic negatively impacted shoot growth greater than foot traffic. In February, no differences were noted between foot traffic and the control, whereas R7 and R9 reduced clipping yield $\approx 28 \%$ compared with the control. No residual effects from winter traffic on shoot growth were noted in May or August.

Shoot chlorophyll concentration was not impacted in December or January, but the control had $\approx 18 \%$ higher chlorophyll concentration compared with F7 in February (Table 5). In May and August, no differences were noted for chlorophyll concentration indicating no winter traffic residual effects.

After 24 foot and rolling traffic applications at 0700 and $0900 \mathrm{HR}$, no impact was noted on soil bulk density or water infiltration

Table 1 . Average monthly canopy and soil $\left(7.6 \mathrm{~cm}\right.$ depth) temperatures $\left({ }^{\circ} \mathrm{C}\right)$ of ' $\mathrm{L} 93$ ' creeping bentgrass during each 24 traffic treatment applications at $0700 \mathrm{HR}, 0900 \mathrm{HR}$, and solar noon from 1 Dec. 2005 and 2006 to 1 Mar. 2006 and 2007.

\begin{tabular}{lccccccc}
\hline & \multicolumn{3}{c}{ Canopy temp $\left({ }^{\circ} \mathrm{C}\right)$} & & \multicolumn{3}{c}{ Soil temp $\left({ }^{\circ} \mathrm{C}\right)$} \\
\cline { 2 - 4 } & December & January & February & & December & January & February \\
\hline $0700 \mathrm{HR}$ & $-4.0 \mathrm{c}^{\mathrm{z}}$ & $-3.1 \mathrm{c}$ & $-3.5 \mathrm{c}$ & & $3.3 \mathrm{~b}$ & $3.5 \mathrm{~b}$ & $2.6 \mathrm{~b}$ \\
$0900 \mathrm{HR}$ & $8.3 \mathrm{~b}$ & $6.8 \mathrm{~b}$ & $7.8 \mathrm{~b}$ & & $3.1 \mathrm{~b}$ & $3.8 \mathrm{~b}$ & $2.6 \mathrm{~b}$ \\
Solar noon & $20.0 \mathrm{a}$ & $17.0 \mathrm{a}$ & $15.2 \mathrm{a}$ & & $6.0 \mathrm{a}$ & $6.7 \mathrm{a}$ & $6.1 \mathrm{a}$ \\
LSD $^{\mathrm{y}}$ & 2.5 & 2.5 & 2.6 & & 1.3 & 1.7 & 1.5 \\
\hline
\end{tabular}

${ }^{2}$ Values within a column followed by the same letter are not significantly different at $P \leq 0.05$ by protected LSD.

${ }^{y_{L S D}}=$ least significant difference.

Table 2. Turfgrass quality of 'L93' creeping bentgrass without (control) and with 24 foot and rolling winter traffic applications at 0700 or $0900 \mathrm{HR}$ recorded after each 24 traffic application dates from 1 Dec. 2005 and 2006 to 1 Mar. 2006 and 2007.

\begin{tabular}{|c|c|c|c|c|c|c|c|c|}
\hline & Day 3 & Day 6 & Day 9 & Day 12 & Day 15 & Day 18 & Day 21 & Day 24 \\
\hline Traffic & \multicolumn{8}{|c|}{ 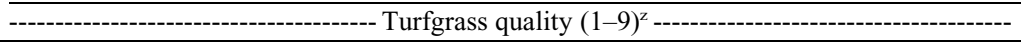 } \\
\hline Controly $^{y}$ & $7.6 \mathrm{a}^{\mathrm{x}}$ & $7.7 \mathrm{a}$ & $7.3 \mathrm{a}$ & $7.5 \mathrm{a}$ & $7.1 \mathrm{a}$ & $7.5 \mathrm{a}$ & $7.0 \mathrm{a}$ & $7.1 \mathrm{a}$ \\
\hline F7 & $6.6 \mathrm{~b}$ & $6.9 \mathrm{bc}$ & $6.3 \mathrm{~b}$ & $6.0 \mathrm{~b}$ & $5.4 \mathrm{c}$ & $5.1 \mathrm{~d}$ & $5.0 \mathrm{c}$ & $4.8 \mathrm{~d}$ \\
\hline F9 & $6.8 \mathrm{~b}$ & $7.1 \mathrm{~b}$ & $6.9 \mathrm{a}$ & $6.5 \mathrm{~b}$ & $6.4 \mathrm{~b}$ & $6.5 \mathrm{~b}$ & $6.3 \mathrm{~b}$ & $5.9 \mathrm{~b}$ \\
\hline R7 & $5.7 \mathrm{c}$ & $5.3 \mathrm{~d}$ & $5.3 \mathrm{c}$ & $5.2 \mathrm{c}$ & $4.3 \mathrm{~d}$ & $4.1 \mathrm{e}$ & $3.8 \mathrm{~d}$ & $3.7 \mathrm{e}$ \\
\hline R9 & $6.8 \mathrm{~b}$ & $6.4 \mathrm{c}$ & $6.3 \mathrm{~b}$ & $6.4 \mathrm{~b}$ & $6.2 \mathrm{~b}$ & $5.6 \mathrm{c}$ & $5.8 \mathrm{~b}$ & $5.4 \mathrm{c}$ \\
\hline LSD & 0.44 & 0.53 & 0.54 & 0.51 & 0.46 & 0.50 & 0.51 & 0.48 \\
\hline
\end{tabular}

${ }^{z}$ Turfgrass quality based on a scale of 1 to 9 in which $1=$ brown/dead turfgrass; $6=$ minimally acceptable turfgrass; $9=$ ideal green, healthy turfgrass.

${ }^{y}$ Control = no traffic; F7 = foot traffic at $0700 \mathrm{HR} ; \mathrm{F} 9=$ foot traffic at $0900 \mathrm{HR} ; \mathrm{R} 7=$ rolling traffic at $0700 \mathrm{HR}$; $\mathrm{R} 9=$ rolling traffic at $0900 \mathrm{HR} ; \mathrm{LSD}=$ least significant difference. Foot traffic consisted of $\approx 75$ steps using SP-4 Saddle Nike golf shoes (soft-spiked sole). Rolling traffic was accomplished using a Toro Greensmaster 800 walk-behind mower.

${ }^{\mathrm{x}}$ Values within a column followed by the same letter are not significantly different at $P \leq 0.05$ by protected LSD.

Table 3. Turfgrass quality of 'L93' creeping bentgrass without (control) and with 24 foot and rolling winter traffic applications at 0700 or $0900 \mathrm{HR}$ recorded weekly and averaged per mo. from Mar. to Aug. 2006 and 2007.

\begin{tabular}{llllccc}
\hline & March & April & May & June & July & August \\
\cline { 2 - 7 } Traffic & $-0-1 \mathrm{a}^{\mathrm{x}}$ & $7.8 \mathrm{a}$ & 7.9 & 7.6 & 7.5 & 6.6 \\
\hline Control $^{\mathrm{y}}$ & $6.2 \mathrm{c}$ & $7.3 \mathrm{~b}$ & 7.8 & 7.6 & 7.5 & 6.4 \\
F7 & $6.5 \mathrm{~b}$ & $7.3 \mathrm{bc}$ & 7.7 & 7.3 & 7.6 & 6.3 \\
F9 & $5.8 \mathrm{~d}$ & $7.0 \mathrm{c}$ & 7.7 & 7.3 & 7.6 & 6.4 \\
R7 & $6.5 \mathrm{bc}$ & $7.3 \mathrm{~b} \mathrm{c}$ & 7.7 & 7.4 & 7.4 & 6.6 \\
R9 & 0.30 & 0.33 & NS & NS & NS & NS \\
LSD & &
\end{tabular}

${ }^{\text {z }}$ Turfgrass quality based on a scale of 1 to 9 in which, $1=$ brown/dead turfgrass; $6=$ minimally acceptable turfgrass; $9=$ ideal green, healthy turfgrass.

${ }^{y}$ Control $=$ no traffic; F7 $=$ foot traffic at $070 \mathrm{HR} ; \mathrm{F} 9=$ foot traffic at $0900 \mathrm{HR} ; \mathrm{R} 7=$ rolling traffic at $0700 \mathrm{HR}$; $\mathrm{R} 9=$ rolling traffic at $0900 \mathrm{HR} ; \mathrm{LSD}=$ least significant difference; $\mathrm{NS}=$ nonsignificant. Foot traffic consisted of $\approx 75$ steps using SP-4 Saddle Nike golf shoes (soft-spiked sole). Rolling traffic was accomplished using a Toro Greensmaster 800 walk-behind mower.

${ }^{x}$ Values within a column followed by the same letter are not significantly different at $P \leq 0.05$ by protected LSD. rates. Also, root TNC in May was unaffected by any winter traffic treatments (Table 6).

\section{Discussion}

When temperatures are at or near freezing, decisions of when to allow normal management operations, like course setup, are generally experience-based. Previous research was lacking on winter traffic damage to bentgrass greens and subsequent performance in the spring and summer in the southern transition zone where golf play continues throughout winter months. Based on these results, time and type of traffic negatively impacted bentgrass winter performance and playability. Regardless of traffic type, traffic at $0900 \mathrm{HR}$ had significantly greater TQ scores than traffic at $0700 \mathrm{HR}$. This can be attributed to more complete frost dissipation because frost melt had occurred by $0900 \mathrm{HR}$ on cloudless mornings. Canopy temperatures on simulated traffic days were consistently below $0{ }^{\circ} \mathrm{C}$ at $0700 \mathrm{HR}$, whereas canopy temperatures at $0900 \mathrm{HR}$ were greater than $6.8^{\circ} \mathrm{C}$. Regardless of traffic type, all treatments were deemed unacceptable after 24 traffic treatments on the coldest days from December to February. However, F9 TQ was at or near the acceptable threshold throughout the winter months. Averaged across all TQ rating dates, $\mathrm{R} 7$ decreased TQ by $\approx 1.1$ units compared with F7. Rolling traffic had more surface discoloration than foot traffic as a result of heavier impacts of the mower. The contact area of the roller was $\approx 115 \mathrm{~cm}^{2}$ (46-cm roller width with $2.5 \mathrm{~cm}$ of the roller consistently contacting the turfgrass surface) with a pressure of $0.80 \mathrm{~kg} \cdot \mathrm{cm}^{-2}$, whereas one foot traffic pressure was $0.31 \mathrm{~kg} \cdot \mathrm{cm}^{-2}$ with a contact area of $240 \mathrm{~cm}^{2}$. Therefore, the walkbehind mower had nearly three times the pressure than foot traffic. Carrow and Petrovic (1992) also indicated added weight increases wear injury. Also, foot traffic was applied in a flat-footed manner with minimal twisting and turning typical on a golf course putting green.

Rolling traffic reduced bentgrass shoot growth $\approx 28 \%$ compared with control; however, chlorophyll, soil bulk density, and water infiltration differences between treatments were not detected in February. Because soil bulk density was unaffected after 24 winter traffic applications, this indicates wear was the primary stress in this study and not soil compaction (Carrow and Petrovic, 1992). Traffic stress on Kentucky bluegrass (Poa Pratensis L.) also reduced shoot growth (Ervin and Koski, 2001). Shoot growth suppression can be attributed to greater weight being applied to the bentgrass surface with possible physical damage to shoot tissues. Further studies are needed to specifically examine winter traffic damages to aboveground tissues. Spring and summer TQ, root TNC, and shoot chlorophyll data indicate winter traffic damage is limited to winter and early spring months. By mid to late spring and throughout summer, all plots fully recovered regardless of winter damage. 
Table 4. Clipping yield ( $\mathrm{g} \cdot \mathrm{m}^{-2}$ ) of 'L93' creeping bentgrass without (control) and with 24 foot and rolling winter traffic applications at 0700 or $0900 \mathrm{HR}$ in winter, spring, and summer months in Years 1 and 2.

\begin{tabular}{|c|c|c|c|c|c|}
\hline \multirow[b]{2}{*}{ Traffic } & December & January & February & May & $\overline{\text { August }}$ \\
\hline & \multicolumn{5}{|c|}{--------------------------- Clipping yield $\left(\mathrm{g} \cdot \mathrm{m}^{-2}\right)$---------------------------- } \\
\hline$\overline{\text { Control }^{2}}$ & $1.74 \mathrm{a}^{\mathrm{y}}$ & $1.55 \mathrm{a}$ & $1.27 \mathrm{a}$ & 1.31 & 1.27 \\
\hline F7 & $1.71 \mathrm{ab}$ & $1.27 \mathrm{bc}$ & $1.21 \mathrm{ab}$ & 1.27 & 1.28 \\
\hline F9 & $1.57 \mathrm{bc}$ & $1.38 \mathrm{ab}$ & $1.16 \mathrm{a}-\mathrm{c}$ & 1.23 & 1.24 \\
\hline R7 & $1.50 \mathrm{c}$ & $1.10 \mathrm{~cd}$ & $1.04 \mathrm{bc}$ & 1.32 & 1.42 \\
\hline R9 & $1.32 \mathrm{~d}$ & $1.04 \mathrm{~d}$ & $0.95 \mathrm{c}$ & 1.26 & 1.32 \\
\hline LSD & 0.17 & 0.23 & 0.22 & NS & NS \\
\hline
\end{tabular}

${ }^{\mathrm{z}}$ Control $=$ no traffic; $\mathrm{F} 7=$ foot traffic at $0700 \mathrm{HR} ; \mathrm{F} 9=$ foot traffic at $0900 \mathrm{HR} ; \mathrm{R} 7=$ rolling traffic at $0700 \mathrm{HR}$; $\mathrm{R} 9=$ rolling traffic at $0900 \mathrm{HR}$; LSD = least significant difference; $\mathrm{NS}=$ nonsignificant. Foot traffic consisted of $\approx 75$ steps using SP-4 Saddle Nike golf shoes (soft-spiked sole). Rolling traffic was accomplished using a Toro Greensmaster 800 walk-behind mower.

${ }^{y}$ Values within a column followed by the same letter are not significantly different at $P \leq 0.05$ by protected LSD.

Table 5. Chlorophyll ( $\mathrm{mg}^{-\mathrm{g}^{-1}}$ ) concentration of ' $\mathrm{L} 93$ ' creeping bentgrass without (control) and with 24 foot and rolling winter traffic applications at 0700 or $0900 \mathrm{HR}$ recorded in winter, spring, and summer months in Years 1 and 2.

\begin{tabular}{lccccc}
\hline & December & January & February & May & August \\
\cline { 2 - 6 } Traffic & 1.91 & 1.60 & $1.34 \mathrm{a}^{\mathrm{y}}$ & 2.68 & 2.66 \\
\hline Control $^{\mathrm{z}}$ & 2.07 & 1.54 & $1.14 \mathrm{~b}$ & 2.77 & 2.66 \\
F7 & 1.97 & 1.58 & $1.21 \mathrm{ab}$ & 2.59 & 2.70 \\
F9 & 2.01 & 1.53 & $1.23 \mathrm{a}$ & 2.58 & 2.78 \\
R7 & 2.04 & 1.53 & $1.21 \mathrm{ab}$ & 2.72 & 2.67 \\
R9 & NS & NS & 0.13 & NS & NS \\
LSD &
\end{tabular}

${ }^{\mathrm{z}} \mathrm{Control}=$ no traffic $; \mathrm{F} 7=$ foot traffic at $0700 \mathrm{HR} ; \mathrm{F} 9=$ foot traffic at $0900 \mathrm{HR} ; \mathrm{R} 7=$ rolling traffic at $0700 \mathrm{HR}$; $\mathrm{R} 9=$ rolling traffic at $0900 \mathrm{HR} ; \mathrm{LSD}=$ least significant difference; NS = nonsignificant. Foot traffic consisted of $\approx 75$ steps using SP-4 Saddle Nike golf shoes (soft-spiked sole). Rolling traffic was accomplished using a Toro Greensmaster 800 walk-behind mower.

${ }^{y}$ Values within a column followed by the same letter are not significantly different at $P \leq 0.05$ by protected LSD.

Table 6. Soil bulk density $\left(\mathrm{g} \cdot \mathrm{cm}^{-3}\right)$ and infiltration rates $\left(\mathrm{cm} \cdot \mathrm{h}^{-1}\right)$ collected end of February and root total nonstructural carbohydrates $(\mathrm{TNC})$ $\left(\mathrm{mg} \cdot \mathrm{g}^{-1}\right)$ collected in May after 24 treatment application dates with and without (control) foot and rolling traffic at 0700 or $0900 \mathrm{HR}$ from 1 Dec. 2005 and 2006 to 1 Mar. 2006 and 2007.

\begin{tabular}{lccc}
\hline & Bulk & & Root \\
Traffic & Density & Infiltration & TNC \\
\hline Control $^{\mathrm{z}}$ & 1.72 & 4.20 & 47.37 \\
F7 & 1.71 & 4.80 & 43.72 \\
F9 & 1.72 & 5.34 & 48.69 \\
R7 & 1.71 & 4.30 & 46.62 \\
R9 & 1.7 & 4.58 & 40.03 \\
LSD & NS & NS & NS \\
\hline
\end{tabular}

${ }^{2}$ Control $=$ no traffic; $\mathrm{F} 7=$ foot traffic at $0700 \mathrm{HR}$; $\mathrm{F} 9=$ foot traffic at $0900 \mathrm{HR} ; \mathrm{R} 7=$ rolling traffic at $0700 \mathrm{HR} ; \mathrm{R} 9=$ rolling traffic at $0900 \mathrm{HR}$; LSD $=$ least significant difference; NS $=$ nonsignificant. Foot traffic consisted of $\approx 75$ steps using SP-4 Saddle Nike golf shoes (soft-spiked sole). Rolling traffic was accomplished using a Toro Greensmaster 800 walk-behind mower.

Results from this study may vary on other field sites as a result of variable microenvironments on golf courses, in particular shade. Although not examined in this study, shaded areas may be more difficult for winter management because surface frost dissipation is slower than greens receiving full early morning sunlight. Also, slopes facing north or northeast receive less direct sunlight during winter morning hours and are more prone to winter injury as a result of prolonged frost periods (McCarty et al., 2005). Winter shade, in combination with winter traffic, is calcium, and potassium), and equipment type. These types of studies should also be conducted on warm-season turfgrass putting greens either overseeded or painted in areas where multiple light to medium frosts occur during winter months. Finally, the impacts of lightly syringing greens to dissipate frost accumulation and subsequent traffic damage warrant investigations.

\section{Literature Cited}

Arnon, D.I. 1949. Copper enzymes in isolated chloroplasts. Polyphenoloxidases in Beta Vulgaris. Plant Physiol. 24:241-249.

Beard, J.B. 1973. Traffic, p. 370-380. In: Beard, J.B. (ed.). Turfgrass: Science and culture. Prentice Hall, Englewood Cliffs, NJ.

Bunnell, B.T., L.B. McCarty, and H.S. Hill. 2001. Summer cultivation effects on a sand based creeping bentgrass golf green. Intl. Turfgrass Soc. Res. J. 9:3-9.

Bunnell, B.T., L.B. McCarty, and H.S. Hill. 2004. Soil gas, temperature, matric potential, and creeping bentgrass growth response to subsurface air movement on a sand-based golf green. HortScience 39:415-419.

Carrow, R.N. and A.M. Petrovic. 1992. Effects of traffic on turfgrasses, p. 285-330. In: Waddington, D.V., R.V. Carrow, and R.C. Shearman (eds.). Turfgrass. Agronomy Monograph 32. ASA, CSSA, SSSA, Madison, WI

Cyril, J., G.L. Powell, R.R. Duncan, and W.V. Baird. 2002. Changes in membrane polar liquid fatty acids of seashore paspalum in response to low temperature exposure. Crop Sci. 42:20312037.

Dionne, J., P.A. Dube, M. Langaniere, and Y. Desjardins. 1999. Golf green soil and crownlevel temperatures under winter protective covers. Agron. J. 91:227-233.

potentially damaging as a result of shorter daylengths, reduced light intensities, and solar elevation angles. These factors can enhance frost accumulation and prolong frost coverage.

Turfgrass practitioners should cautiously proceed when allowing traffic on turfgrass surfaces immediately after frost melt. It appears the contributing factor for increased surface discoloration was weight of traffic. Although foot traffic was less damaging than equipment traffic, some surface discoloration was noted. However, once temperatures moderated, late spring and summer differences were not detected. Therefore, if winter injury occurs on a bentgrass green in the eastern part of the transition zone, full recovery should be expected when temperatures consistently remain above freezing.

Future studies should investigate winter traffic impacts at further divided time intervals (i.e., 0730, 0800, 0830, 0900, or $0930 \mathrm{HR}$ ) and temperature ranges (i.e., -1 to $2{ }^{\circ} \mathrm{C}, 2$ to $4{ }^{\circ} \mathrm{C}$, or 5 to $7{ }^{\circ} \mathrm{C}$ ) to monitor the traffic impacts. This type of future study will effectively predict what temperatures and times vehicular or foot traffic could be allowed on bentgrass putting greens during winter months with minimal damage and efficient time management for play and maintenance. In addition, creeping bentgrass cultivars may perform differently in response to frost day traffic associated with different root zone mixtures, fertility regimes (i.e., nitrogen,
Ebdon, J.S., R.A. Gagne, and R.C. Manley. 2002. Comparative cold tolerance in diverse turf quality genotypes of perennial ryegrass. HortScience 37:826-830.

Ervin, E.H. and A.J. Koski. 2001. Kentucky bluegrass growth responses to trinexapac-ethyl, traffic, and nitrogen. Crop Sci. 41:18711877.

Fry, J. and B. Huang. 2004. Temperature stresses, p. 83-88. In: Fry, J. and B. Huang (eds.). Applied turfgrass science and physiology. John Wiley and Sons, Inc., Hoboken, NJ.

Guertal, E.A., E. van Santen, and D.Y. Han. 2005 Fan and syringe application for cooling bentgrass greens. Crop Sci. 45:245-250.

Gusta, L.V., J.D. Butler, C. Rajashekar, and M.J. Burke. 1980. Freezing resistance of perennial turfgrasses. HortScience 15:494-496.

Gusta, L.V., R.W. Wilen, and P. Fu. 1996. Low-temperature stress tolerance: The role of abscisic acid, sugars, and heat-stable proteins. HortScience 31:39-46.

Hiscox, J.D. and G.F. Israelstam. 1979. A method for the extraction of chlorophyll from leaf tissue without maceration. Can. J. Bot. 57: 1332-1334.

Huang, B. 2001. Summer bentgrass decline: Causes and cures. Golf Course Management. 69:61-64.

Huang, B. and H. Gao. 2000. Growth and carbohydrate metabolism of creeping bentgrass cultivars in response to increasing temperatures.

McCarty, L.B., C. Wells, G. Miller, and G. Landry, Jr. 2005. Turfgrass physiology and environmental stress, p. 80-94. In: McCarty, L.B. (ed.). Best golf course management practices. Crop Sci. 40:1115-1120. 
2nd Ed. Prentice Hall, Upper Saddle River, NJ.

McCullough, P.E., H. Liu, L.B. McCarty, T. Whitwell, and J.E. Toler. 2006. Bermudagrass putting green growth, color, and nutrient partitioning influenced by nitrogen and trinexapacethyl. Crop Sci. 46:1515-1525.

Nelson, N. 1944. A photometric adaptation of the Somogyi method for determination of glucose. J. Biol. Chem. 153:375-381.

Rajashekar, C., D. Toa, and P.H. Li. 1983. Freezing resistance and cold acclimation in turfgrasses. HortScience 18:91-93.

Rodriguez, I.R., L.B. McCarty, and J.E. Toler. 2005. Effects of misting and subsurface air movement of bentgrass putting greens. Agron. J. 97:1438-1442.
SAS Institute Inc. 2005. SAS version 9.1. SAS Inst., Cary, $\mathrm{NC}$.

Somogyi, M. 1945. Notes on sugar determination. J. Biol. Chem. 195:19-23.

Tompkins, D.K., J.B. Ross, and D.L. Moroz. 2000. Dehardening of annual bluegrass and creeping bentgrass during late winter and early spring. Agron. J. 92:5-9.

Tompkins, D.K., J.B. Ross, and D.L. Moroz. 2004. Effects of ice cover on annual bluegrass and creeping bentgrass putting greens. Crop Sci. 44:2175-2179.

U.S. Golf Association Green Section Staff 1993. USGA recommendations for a method of putting green construction. The 1993 revision. USGA Green Section Record. 31: $1-3$.
Valverde, F.J. and D.D. Minner. 2007. Field evaluation of winterkill in annual bluegrass and creeping bentgrass: Creeping bentgrass is unaffected by ice cover, but annual bluegrass can suffer substantial injury. Golf Course Management 75:88-93.

Webster, D.E. and J.S. Ebdon. 2005. Effects of nitrogen and potassium fertilization on perennial ryegrass cold tolerance during deacclimation in late winter and early spring. HortScience 40:842-849.

White, C. 1984. Playing par with Jack Frost. USGA Green Section Record. 22:8-11.

$\mathrm{Xu}, \mathrm{Q}$. and B. Huang. 2000. Growth and physiological responses of creeping bentgrass to changes in air and soil temperatures. Crop Sci. 40:1363-1368. 